\title{
Usability of volumetric infusion pumps in pediatric intensive care
}

\author{
Usabilidade de bombas de infusão volumétricas em terapia intensiva pediátrica \\ Usabilidad de bombas de infusión volumétrica en cuidados intensivos pediátricos
}

How to cite this article:

Oliveira ECS, Silva RCL, Arruda GA, Oliveira RC. Usability of volumetric infusion pumps in pediatric intensive care. Rev Esc Enferm USP. 2021;55:e03712. doi: https://doi.org/10.1590/S1980-220X2020001103712

\section{Elizandra Cassia da Silva Oliveira ${ }^{1}$ \\ Roberto Carlos Lyra da Silva² \\ Gustavo Aires de Arruda ${ }^{3}$ \\ Degina Célia de Oliveira ${ }^{1}$}

\footnotetext{
${ }^{1}$ Universidade de Pernambuco, Escola de Enfermagem, Programa de Pós-Graduação em Enfermagem, Recife, PE, Brazil.

2 Universidade Federal do Estado do Rio de Janeiro, Escola de Enfermagem Alfredo Pinto, Programa de Pós-Graduação em Enfermagem, Rio de Janeiro, RJ, Brazil.

${ }^{3}$ Universidade Estadual de Londrina, Centro de Educação Física e Esporte, Londrina, PR, Brazil
}

\begin{abstract}
Objective: To analyze the usability of two infusion pump models in a Pediatric Intensive Care Unit. Method: This is a cross-sectional study of exploratory descriptive quantitative approach. A task was carried out in a controlled environment using infusion pump with 72 nursing staff members from August to September 2018. The Methodological Guideline for Medical Care Equipment Assessment Studies and the quality model proposed by NBR ISO/IEC 9126-1 were followed. Descriptive statistical analysis was used applying Fisher's exact test, binomial test and Mann-Whitney test. Results: $91.7 \%$ of tasks were completed. The infusion pump-2 model was associated $(p<0.001)$ with operationalization, tasks accomplished with non-conformities, use of a manual calculator (measure effectiveness) and task accomplishment time (measure efficiency). Conclusion: Efficacy and efficiency measures can evidence a better context of usability of IPs and identify interaction failures with the nursing staff to be improved in care practice.
\end{abstract}

\section{DESCRIPTORS}

Infusion Pumps; Intensive Care Units, Pediatric; Ergonomics; Pediatric Nursing; Quality of Health Care; Technology Assessment, Biomedical. 


\section{INTRODUCTION}

In Pediatric Intensive Care Units (PICUs), among so many equipment, infusion pump (IP) is a widely used medical care equipment (MCE). MCE is defined as an equipment or system, including its accessories, used directly or indirectly for diagnosis, therapies and monitoring in the population's health care ${ }^{(1)}$.IP is an essential ally to the nursing staff in the process of administration of fluids (hydration, replacement and correction with crystalloides or colloides), diets, and medications safely ${ }^{(2)}$. When using an IP, human-equipment interaction is critical, requiring users to configure it to ensure its full functionality ${ }^{(3)}$. This interaction is assessed through the equipment usability, i.e., the way it is used by specific professionals to achieve specific goals with effectiveness, efficiency, and satisfaction in a specific context of use $\mathrm{e}^{(4-5)}$. It should be, in care practice, an easy-to-learn and handling equipment.

Analysing the usability of MCEs, interfaces and software is an imperative for nurses in intensive care environments. This type of analysis provides necessary information about cognitive workload, workflow, changes, and errors that can occur due to the design of a deficient technology and/or due to users' lack of ability ${ }^{(6-7)}$. Certainly, it is expected that health equipment will be designed for the maximum benefit of its final result to patients, provided that there is an effective interaction with those who handle them. Thus, the importance of a positive safety culture is reinforced, in which identifying weaknesses in work processes by professionals enables improvements that can ensure patient safety as a priority ${ }^{(8)}$.

Although IP provides reliable and effective drug administration in the hospital context, problems related to its usability are observed in literature, such as: old-fashioned devices and software, which do not meet users' needs for the complexity of medications and fluids to be administered; unsimplified manual programming, which requires a series of non-obvious keystrokes; reduced screen size, which impairs visibility; among others ${ }^{(9-10)}$. These factors may favor the occurrence of errors during their use, which, in turn, reduce patient safety. Tied to all this, one has the human fallibility disclosed by James Reason, who warns us to build mechanisms that minimize in care practice the risks arising from infusion therapies using $\mathrm{IPs}^{(11)}$.

Therefore, there are few studies on the possible design flaws in IPs and the technical ability of its users in PICUs; those already available are incipient and are limited to using IP for adult patients. For instance, incorrect or incomplete schedules have been the main cause of medication errors using smartpumps due to the complexity of its interface ${ }^{(12)}$. Continuous infusion errors of multiple medications (piggyback function) and bolus infusion that present more serious outcomes to patients are also other examples ${ }^{(13)}$.

In PICUs, it is verified that the incidence of errors and adverse events with medications are two to three times higher than in adult intensive care ${ }^{(14)}$. This fact may be related to the heterogeneity of the characteristics of hospitalized patients, from infants to adolescents, which requires varied doses and time of drug infusion. It is common to prescribe drug doses that use multiples of 10 (in which the absence or addition of the number 0 makes all the difference), doses calculated by time or weight that require using decimal numbers (unit/kilo/ hour or unit/hour) and administration of prolonged drugs with low flow ${ }^{(14-15)}$. Moreover, high-surveillance and/or offlabel medications are administered continuously, which are those prescribed differently to the instructions on the package insert or official compendiums regarding dose, indication, age group, interval or form of administration ${ }^{(16)}$, requiring greater skill and scientific knowledge in handling IPs by users.

The Food and Drug Administration revealed that the operational complexity of IPs led to 56,000 adverse drug events over a 4-year period, some of which resulted in serious events and deaths ${ }^{(17)}$. The American Emergency Care Research Institute (ECRI) pointed out the IP configuration in the TOP 10 list of "Alarm Hazards"(18).

Considering the above and the importance of patient safety related to correct handling of IPs, the following question is pertinent: how are IPs handled by the PICU nursing staff? The study aimed to analyze the usability of two IP models in PICUs.

\section{METHOD}

\section{STUdY DESIGN}

This is a cross-sectional study of exploratory descriptive quantitative approach, based on assessment of health technologies involving MCEs. The methodological framework used was the Methodological Guideline for Medical Care Equipment Assessment Studies (Diretriz Metodológica para Estudos de Avaliação de Equipamentos Médicos-Assistenciais) ${ }^{(1)}$ and the Quality Model in use proposed by NBR ISO/IEC 9126-1 ${ }^{(19)}$.

The Methodological Guideline for Medical Care Equipment Assessment Studies has six areas of analysis: clinical; technical; admissibility; economic; operational; innovation. To assess the human-equipment interaction, the operational domain was chosen, which assesses the variables that can influence the technology's performance by human factors and ergonomics; thus, one chose the usability item. The usability-efficiency measure was defined as a relationship between effectiveness and cost to obtain it, generally expressed according to the amount of effort required to meet a goal, preferably through the least effort possible. In this study, the parameter used was time spent to perform IP programming.

ISO/IEC 9126-1, entitled Software Engineering, defines product quality based on the following parameters: quality model, external metrics, internal metrics, and quality metrics in use. To assess the quality metrics in use of the software, among the specific goals (efficacy, productivity, safety and satisfaction) to be achieved, one opted for the usability-efficacy measure, defined as the ability of a software product to allow users to achieve specific goals, with accuracy and completeness, in a specific use context. In this study, the parameter used was the percentage of users successfully completing IP programming. 


\section{SETTING}

The study scenario included two public pediatric ICUs in the metropolitan region of Recife, Pernambuco state, which showed similarity in the clinical profile of pediatric patients assisted, number of beds and employees, models of IPs with the time of their use for at least one year.

The equipment used were two volumetric IP models, designed to regulate the flow of liquids administered to patients under positive pressure generated by the pump by circular peristaltic mechanism for IP-1 and linear type peristaltic for IP-2. Its flows are determined by users in volume per unit of time $(\mathrm{ml} / \mathrm{h})$ in adult or pediatric mode, thus incorporating all safety requirements set forth in NBR IEC 60601-2-24 norm ${ }^{(20)}$.

The study population understood as IP users was composed of nursing staff (nurses and nursing technicians).

\section{SAMPLE DEFINITION}

The inclusion criterion was to perform care activities with handling IP for a minimum period of one year. The selection was by census. After presenting the study objective and signing the Informed Consent Form (ICF), 42 professionals in PICU-A who used IP-1 and 30 professionals in PICU-B who used IP-2 participated in the study.

\section{Data Collection}

Data collection occurred from the observation of a task, in a controlled environment, due to the need for data accuracy during the collection involving different users and the possibility of further comparison. The controlled environment was designed in a specific room in each ICU, avoiding interference from noise, lighting, or other users. There was an IP for prompt use: connected to the electricity grid, preventive maintenance with validated date and specific transfuser already installed. The research participants moved individually during the shift to this environment, where it was requested to perform a task that consisted of programming IPs to infuse $528.3 \mathrm{ml}$ of total volume over 12 hours, resulting in a flow rate of $44 \mathrm{ml} / \mathrm{h}$.

To measure the effectiveness of IP, a checklist was used and filled out step by step for its configuration according to the manufacturers' recommendations, summarized in Chart 1.

The task accomplished could be classified as:

"In conformity", when the step by step was achieved without errors, obtaining the correct flow result; "Task accomplished with non-conformities", when the step by step was performed with errors and still, the correct flow result was obtained; "Task not accomplished", when, at the end, the flow result was different than expected.

The use of a manual calculator as a device for performing numerical calculations including volume and infusion time was noticed. This item was observed during a task accomplished by users, who, not knowing how to use the function in IP, used a manual calculator.

In the usability-efficiency measure, the time spent to accomplish tasks that obtained the correct result of the expected flow was timed and recorded.
Chart 1 - Operationalization according to infusion pump model - Recife, PE, Brazil, 2018.

\begin{tabular}{|l|l|l|l|}
\hline \multirow{2}{*}{ Step by step - Infusion pump-1 } & \multicolumn{2}{|c|}{ Conformity } \\
\cline { 3 - 4 } & Yes & No \\
\hline Step 1 & Press the key O. & & \\
\hline Step 2 & Wait for the self-test routine. & & \\
\hline Step 3 & $\begin{array}{l}\text { Initial screen: program infusion - press the } \\
\text { "confirm" key. }\end{array}$ & & \\
\hline Step 4 & $\begin{array}{l}\text { Press "up" or "down" key and select the type } \\
\text { of schedule for use in: NEO patient. }\end{array}$ & & \\
\hline Step 5 & Press the "confirm" key. & & \\
\hline Step 6 & Program the infusion volume=528.3. & & \\
\hline Step 7 & Press the "confirm" key. & & \\
Step 8 & Infusion flow - press the "confirm" key. & & \\
\hline Step 9 & Schedule infusion time=12 hours. & & \\
\hline Step 10 & Press the "confirm" key. & & \\
\hline Task accomplishment time= & & \\
\hline
\end{tabular}

\begin{tabular}{|l|l|c|c|}
\hline \multirow{2}{*}{ Step by step - Infusion pump-2 } & \multicolumn{2}{c|}{ Conformity } \\
\cline { 3 - 4 } & Yes & No \\
\hline Step 1 & Press the "on/off" key. & & \\
\hline Step 2 & Wait for the self-test routine. & & \\
\hline Step 3 & $\begin{array}{l}\text { Press the F key and sequentially key 2 } \\
\text { (program the total volume to be infused). }\end{array}$ & & \\
\hline Step 4 & Program the infusion volume=528.3. & & \\
\hline Step 5 & Press the F key (confirm). & & \\
\hline Step 6 & $\begin{array}{l}\text { Press the F key and sequentially the key 4 } \\
\text { (P=volume programming drops/minutes). }\end{array}$ & & \\
\hline Step 7 & Schedule infusion time=12 hours. & & \\
\hline Step 8 & Press the F key (confirm). & & \\
\hline Task accomplishment time= & & \\
\hline
\end{tabular}

The task was reproduced in day and night shifts on three consecutive days in the PICU of each hospital. Checklist completion, timing and time recording were performed by only one researcher. The interest-dependent variables were step by step conformity and non-conformity; number of tasks accomplished; use of a manual calculator; task accomplishment time. The independent variables were IP (IP-1 and IP-2). Considering that recent training would be an intervening potential variable, this was investigated with the nursing coordinations of the two PICUs before the study, and it was verified that there was no training. Furthermore, professional experience (years) was tested as an intervening potential variable for usability indicators (time and task accomplishment); however, it did not present statistical significance.

\section{DATA ANALYSIS AND TREATMENT}

Descriptive statistics (measures of central tendency and dispersion) was used for equipment characterization. The binomial test was used to verify whether the proportion of conformity with the IPs checklist was different from the ran$\operatorname{dom}(50 \%)$. The statistical significance adopted was $\mathrm{p}<0.05$.

\section{ETHICAL ASPECTS}

The research project was approved by the Research Ethics Committee of the HUOC/PROCAPE Hospital 
Complex, under Protocol 2.835.374, 2018. The study met the ethical criteria in research with human beings, in accordance with Resolution 466/12 of the Brazilian National Health Council. The Informed Consent Form was signed by participants.

\section{RESULTS}

Seventy-two nursing professionals were assessed, of whom 58 were nursing technicians and 14 were nurses. Women figured prominently, with a mean age of 38 years and time of experience above 10 years performing care activities to patients in PICU using IP. Regarding IP operationalization characterization, it was observed in Table 1 that, for IP-1, all steps of the checklist had a significantly higher frequency of conformity than the randomly expected ( $\mathrm{p}$ 0.001), except for the step "Wait for the self-test routine". For IP-2, among the eight stages analyzed, four presented significantly higher conformity than randomly expected ( $\mathrm{p}$ $<0.001$ ) and one had significantly lower conformity than randomly expected $(\mathrm{p}=0.043)$.

Table 1 - Operationalization of infusion pumps by the nursing staff in Pediatric Intensive Care Unit according to the infusion pump model - Recife, PE, Brazil, 2018.

\begin{tabular}{|c|c|c|c|}
\hline \multirow[t]{2}{*}{ Operationalization } & Conformity & $\begin{array}{c}\text { Non- } \\
\text { conformity }\end{array}$ & \multirow[t]{2}{*}{$\mathrm{p} \neq$} \\
\hline & n(\%) & $\mathrm{n}(\%)$ & \\
\hline \multicolumn{4}{|l|}{ *PICU-A/+IP-1 } \\
\hline Press the key ${ }^{\odot} \dot{0}$ & $42(100)$ & $0(0)$ & $<0.001$ \\
\hline Wait for the self-test routine & 26(61.9) & $16(38.1)$ & 0.164 \\
\hline $\begin{array}{l}\text { Home screen: infusion program: } \\
\text { press the confirm key }\end{array}$ & $42(100)$ & $0(0)$ & $<0.001$ \\
\hline $\begin{array}{l}\text { Press key up or down and select } \\
\text { the type of schedule for use in: } \\
\text { NEO patient }\end{array}$ & $40(95.2)$ & $2(4.8)$ & $<0.001$ \\
\hline Press the confirm key & $42(100)$ & $0(0)$ & $<0.001$ \\
\hline $\begin{array}{l}\text { Program the infusion } \\
\text { volume }=528.3\end{array}$ & 39(92.9) & $3(7.1)$ & $<0.001$ \\
\hline Press the confirm key & $41(97.6)$ & $1(2.4)$ & $<0.001$ \\
\hline $\begin{array}{l}\text { Infusion flow - press the confirm } \\
\text { key }\end{array}$ & $40(95.2)$ & $2(4.8)$ & $<0.001$ \\
\hline Schedule infusion time $=12$ hours & $40(95.2)$ & $2(4.8)$ & $<0.001$ \\
\hline Press the confirm key & $41(97.6)$ & $1(2.4)$ & $<0.001$ \\
\hline \multicolumn{4}{|l|}{ *PICU-B/**IP-2 } \\
\hline Press the on/off key & $30(100)$ & $0(0)$ & $<0.001$ \\
\hline Wait for the self-test routine & $30(100)$ & $0(0)$ & $<0.001$ \\
\hline $\begin{array}{l}\text { Press the F key and sequentially } \\
\text { key } 2 \text { (program the total volume } \\
\text { to be infused) }\end{array}$ & $30(100)$ & $0(0)$ & $<0.001$ \\
\hline $\begin{array}{l}\text { Program the infusion } \\
\text { volume }=528.3\end{array}$ & $30(100)$ & $0(0)$ & $<0.001$ \\
\hline Press the F key (confirm) & $10(33.3)$ & $20(66.7)$ & 0.099 \\
\hline $\begin{array}{l}\text { Press the F key and sequentially } \\
\text { key } 4 \text { (volume programming } \\
\text { drops/minutes) }\end{array}$ & 10(33.3) & $20(66.7)$ & 0.099 \\
\hline Schedule infusion time $=12$ hours & $9(30.0)$ & $21(70.0)$ & 0.043 \\
\hline Press the F key (confirm) & $10(33.3)$ & $20(66.7)$ & 0.099 \\
\hline
\end{tabular}

*PICU - Pediatric Intensive Care Unit; ${ }^{\dagger} \mathrm{IP}$ - Infusion pump; ‡Binomial Test. Note: $\mathrm{n}=72$.
Table 2 assesses efficacy measure, verifying that the mean of the task accomplished by IP- 1 and IP-2 users was $91.7 \%$. However, for IP-1, there were $4.8 \%$ of tasks that were not accomplished when compared to $13.3 \%$ of tasks not accomplished for IP-2. There was statistical significance related to task accomplishment and quantity of non-conformities. Concerning accomplishing tasks, it was observed that $55 \%$ of study participants who handled IP-1 did so accordingly, while only $30 \%$ for participants who handled IP-2. The presence of four non-conformities for accomplishing the task performed was $67.5 \%$ in IP-2, not being evidenced for IP-1.

Regarding the use of a manual calculator, it was not observed among IP-1 users, whereas, for IP-2 users, 56.7\% used it with statistical significance.

Table 2 - Efficiency in infusion pump usability by the nursing staff in a Pediatric Intensive Care Unit according to the infusion pump model - Recife, PE, Brazil, 2018.

\begin{tabular}{lccc}
\hline \multirow{2}{*}{ Variable } & \multicolumn{2}{c}{ Infusion pump } & \multirow{2}{*}{ P value } \\
\cline { 2 - 3 } & $\mathbf{1}$ & $\mathbf{1}$ & \multirow{2}{*}{0.237} \\
\cline { 2 - 3 } Task accomplished & & & \\
Yes & $40(95.2)$ & $26(86.7)$ & \\
No & $2(4.8)$ & $4(13.3)$ & \\
\hline Task accomplished* & & & $<0.001+$ \\
Conformity & $22(55.0)$ & $9(34.6)$ & \\
One non-conformity & $15(37.5)$ & $0(0)$ & \\
Two non-conformities & $2(5.0)$ & $0(0)$ & \\
Three non-conformities & $1(2.5)$ & $0(0)$ & \\
Four non-conformities & $0(0)$ & $17(65.4)$ & \\
\hline Use of a manual calculator & & & $<0.001+$ \\
Yes & $0(0)$ & $17(56.7)$ & \\
No & $42(100)$ & $13(43.3)$ & \\
\hline
\end{tabular}

"Considering only the tasks accomplished; ${ }^{+}$Fisher's exact test. Note: $n=72$.

For the usability-efficiency presented in Figure 1, statistical significance was identified regarding the time taken to accomplish a task, which, for IP-1, presented an average of 38.5 seconds (ranging from 28 to 48.2 seconds); in IP-2, the mean was 75 seconds (ranging from 34 to 105 seconds).

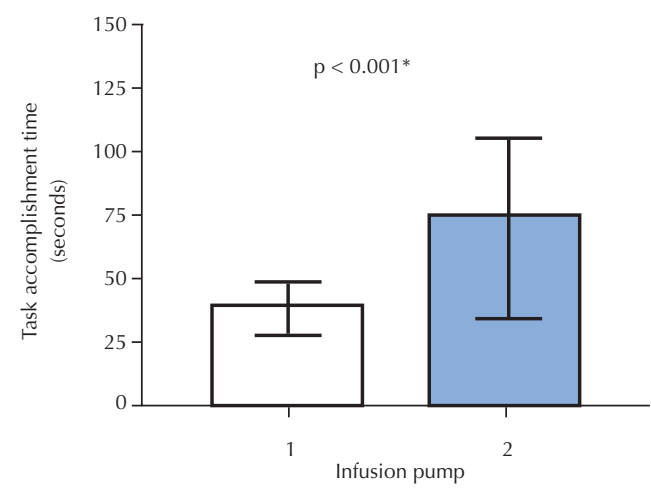

"Mann-Whitney Test; median and interquartile interval. Note: $(n=72)$.

Figure 1 - Efficiency in infusion pump usability by the nursing staff in a Pediatric Intensive Care Unit according to the infusion pump model - Recife, PE, Brazil, 2018. 


\section{DISCUSSION}

In an analysis of IP usability in PICUs with the nursing staff as users, failure in its operationalization resulted in deviations from the rules of use established by its manufacturers. Normative deviations in usability studies are important indicators for the safety of interactive systems. While not avoiding all errors, they bring visibility to specific guidance for substantial improvements to the interfaces of $\mathrm{IPs}^{(10)}$.

Regarding IP-1 operationalization, the mandatory selftest before using the equipment was not observed by $38.1 \%$ of its users, standing out among the steps assessed as the only not significantly inferior expected at random $(\mathrm{p}=0.164)$. During the accomplishment of the proposed task, users' speed to accomplish a task was observed as soon as they switched on the equipment, showing that the self-test was not performed. The IP self-test, according to the manufacturer's instructions, is a safety routine that must be performed every time the equipment is turned on. At this time, the equipment performs self-checking of its functions, and it is necessary to observe the audiovisual alarms' functioning, the drip indicator and the seven-segment display. No infusion session should be initiated if any abnormality in the audiovisual indicators' functioning is found, much less if the 3 digits of the 7-segment display do not indicate the number 888 , ending the routine with 000 .

According to the Swiss cheese model presented by Reason, the slices of cheese with an opening that line up result in adverse events to patients ${ }^{(11)}$. In this scenario, the self-test acts as a barrier in the identification of equipment failures, in order to prevent errors from reaching patients, thus confirming its importance during IP operationalization. As in aviation, health equipment must be classified as complex systems, requiring standardized routines that prevent human violations and errors ${ }^{(8)}$. Ideally, if the self-test was not carried out, the IP would "crash", not allowing its operation. This would guarantee implementing a defensive barrier in using the equipment.

Overconfidence in the equipment because it is considered fault-free can also lead to normative deviations. Therefore, in view of the occurrence of some adverse event involving IP, only failures in professional competence and/ or technical unpreparedness will be analyzed, since what is required by the manufacturer is not performed. Although it seems paradoxical that equipment can act as error inducers, these are defined as errors arising from the development and design of the equipment and will often only be evidenced after its implementation in practice ${ }^{(21)}$. From this perspective, nursing staff's care practice associated with the study of usability is essential in assessment and co-participation in developing IPs that permeate care, ensuring effective results to patients.

In the operationalization of BI-2, it is emphasized that $66.7 \%$ to $70 \%$ of its users did not know how to program the flow rate of IP by time of infusion, revealing itself as significantly lower expected random ( $\mathrm{p}=0.043)$ among the step by step phases. For this function to be performed, the desired volume and infusion time must be reported in the medical prescription. When entering these two parameters in IP, it automatically performs the infusion flow from the programmed volume and time. However, as in accomplishing the proposed task, the infusion flow was not pre-established for users to just type; they did not know how to execute programming on the pump using the volume and infusion time data.

A study conducted at the Christiana Care Health System Virtual Education and Simulation Training Center through a usability test with IP simulation observed, indirectly, that $68 \%$ of its participants had failures when handling IP; $86 \%$ after performing a self-assessment revealed that they experienced usability problems during the simulated test. The results of this simulation evidenced vulnerabilities and potential opportunities for improvement in IP; for instance, it was pointed out that multifunctional keys made its usability difficult ${ }^{(22)}$.

In line with these findings, the difficulty in operationalizing IP has been evidenced as the cause of possible adverse events. A study carried out at a children's hospital located in the Midwest, USA revealed that the discrepancy between what was prescribed and what was programmed in IP was $24.3 \%$ for medications and $42.4 \%$ for fluids ${ }^{(23)}$. Lapses and slips were also reported in scheduling fluid infusion in IPs in Brazilian hospitals: a vasoactive drug that was infusing 10 $\mathrm{m} / / \mathrm{h}$ when the prescription was $1 \mathrm{ml} / \mathrm{h}$; parenteral nutrition prescribed at $62.5 \mathrm{ml} / \mathrm{h}$ when it was being infused at 625 $\mathrm{ml} / \mathrm{h}$, with possible fatal damage to patients ${ }^{(24)}$.

In the pediatric context, implementing new IP smartpumps, when assessed through analysis of modes and failures, several points of risk during the implementation and use process were also found by its users ${ }^{(25)}$. However, improvements were suggested through the role of the staff itself, such as introducing capital letters to help users differentiate names of similar drugs, promoting more safety in the use of equipment and improvements in care practice.

In the evidence of difficulties when using IP, a safety culture must be reinforced in order to focus not on the identification of culprits, but on the factors that contribute to users not programming the equipment correctly. In practical experience, it is observed that training is quick, without periodicity, little depth, in-service, and often interrupted by complications from patients. A usability study on medical equipment also shows that little investment in training is a barrier to the safe use of infusion pumps, reporting as one of the main causes for the staff's failure to use $\mathrm{MCEs}^{(26)}$.

Periodic training in MCE should be regular, regardless of the occurrence of adverse events or difficulties by users. Studies reveal that the effects of learning related to interactive systems have on the repeated task and monitoring of learning a better performance of users, since it can be identified normative deviations and mental effort (concentration to use the equipment) of users to accomplish some task $\mathrm{k}^{(26-27)}$.

When there are problems with the usability of an equipment, the development of alternative solutions is created by users to ensure that the equipment does not harm their daily activities ${ }^{(28)}$. Alternative solutions are defined as formal 
practices that do not follow explicit or implicit rules, and may negatively influence the safety and efficacy of care offered together to medical care equipment, mainly because they hide their deficiencies. Regarding the efficacy assessed during IP usability, it was observed that, despite the high accomplishment of a task by both users, the amount of use of alternative solutions (64.5\%) to be able to achieve the task successfully by users of IP-2 was evidenced by the breach of the step by step required by the manufacturer.

Thus, workarounds are a result of the lack of interaction between users and the equipment in meeting their needs in the real work environment. In this context, the equipment becomes inefficient by low communication with users, hindering the workflow efficiency. Regarding the IP-2 users, the use of a manual calculator was also observed, reinforcing alternative solutions that promote the underutilization of IP functions, which can reduce the safety and quality of patient care. A study in Hong Kong, which assessed the usability of four types of IP in a simulated video environment, showed, by it called "procedure deviation", a total deviation/IP: 111, 70, 24 and 13, respectively. Also, 72\% were classified as critical deviations, demonstrating a criterion to be assessed with regard to usability ${ }^{(29)}$.

Understanding the interaction difficulties between users and the equipment promotes a reflection on the project idealized in laboratories and the real one experienced in practice $^{(13)}$. This process generates improvements in the equipment based on users' needs. Nursing staff-equipment interaction stands out as a foundation for its development, becoming a strategy that improves nursing care reflected in users' positive satisfaction during its usability.

Therefore, adherence to usability principles (user needs, context in which the product is used and its interaction with users) should result in intuitive devices that require little training, making errors difficult and, if they occur, they are recognized and corrected immediately ${ }^{(29)}$. It is necessary to emphasize that human fallibility cannot be adapted according to the design of the projected technology.

In assessing IP efficiency, the time spent to accomplish the proposed task was statistically significant for IP-2 users. With this result, it can be inferred that the low efficiency observed in this group of users may also have interfered with the low efficiency in accomplishing the task when compared to IP-1 users.

IP usability studies, in agreement with this study, observed that the low effectiveness also leads to low efficiency in the time accomplishing a task ${ }^{(10,27)}$. It is important to note that the exclusive focus on the time for accomplishing a task, even in ICUs, can be a predictor of errors, since it can encourage users to navigate through IP interface quickly and not noticing the step by step required by manufacturers.
It is worth mentioning a study carried out in Boston, which assessed the time spent by its participants to accomplish tasks and the frequency of errors made; it was revealed that the longer it takes to program an IP, the more frustrated a user will become and the more likely it is that there will be an error in medication administration ${ }^{(12)}$. What was similarly observed in this research is that the greater the time spent to accomplish the task in IP-2, the greater the number of non-conformities in its operationalization.

In this context, implementing human factors engineering has been gaining visibility in the context of health ${ }^{(21)}$. It is supported by the FDA as part of the design process at each stage of the medical device development process. The risks arising from the interaction of human beings with the technology introduced in their real work environment are identified so that there is a better effectiveness, efficiency, and satisfaction of this interaction ${ }^{(7)}$. Scientific evidence reveals that little investment in human factors engineering related to the design and implementation of technologies can result in low quality of care, incidents that put patient safety at risk and undesirable results for professionals and organization, such as job dissatisfaction, burnout, injuries, and high turnover ${ }^{(30)}$.

Certainly, nursing care in pediatric intensive care is linked to the effectiveness and efficiency of handling the IP used. This interaction results in benefits and/or adverse events to patients, which reflect on the quality of care provided and optimization of nursing work. In Brazil, studies involving IP usability are even more incipient in the pediatric context. However, among the limitations identified in this study, one can mention the possible interference of the researcher's presence in the performance of the research participants in carrying out the test; as well as recent trainings, carried out in other services, if the participants worked using the same model of IPs assessed.

\section{CONCLUSION}

The usability assessment through effectiveness and efficiency measures showed a better usability context in PICU-A using IP-1; interaction failures with the nursing staff were identified to be improved in both IP models.

Periodic training and monitoring of the care process related to using IP strengthen the importance of nursing staff as a foundation in the design, assessment and improvement in the levels of IP usability, since safe care depends on this effective interaction.

Future studies are proposed that point out adverse events associated with IP usability in order to give visibility to this theme, since, providing improvements in this process, effective defensive barriers will strengthen patient safety and the quality of nursing care.

\section{RESUMO}

Objetivo: Analisar a usabilidade de dois modelos de bomba de infusão em Unidade de Terapia Intensiva Pediátrica. Método: Estudo com delineamento transversal de abordagem quantitativa do tipo descritivo exploratório. Realizou-se em um ambiente controlado uma tarefa utilizando a bomba de infusão com 72 integrantes da equipe de enfermagem no período de agosto a setembro de 2018 . Como base, seguiu-se a diretriz metodológica para estudos de avaliação de Equipamentos Médicos-Assistenciais e o modelo de qualidade em uso proposto pela NBR ISO/IEC 9126-1. Utilizou-se a análise estatística descritiva, aplicando o Teste Exato de Fisher, o Teste Binomial e o Teste de Mann-Whitney. Resultados: Constataram-se 91,7\% de tarefas cumpridas. O modelo da bomba de infusão-2 
apresentou associação $(p<0,001)$ com a operacionalização, tarefas cumpridas com não conformidades, uso da calculadora manual (medida eficácia) e o tempo para cumprir a tarefa (medida eficiência). Conclusão: Medidas de eficácia e eficiência podem evidenciar um melhor contexto de usabilidade de bombas de infusão e identificar falhas de interação com a equipe de enfermagem a serem aprimoradas na prática assistencial.

\section{DESCRITORES}

Bombas de Infusão; Unidades de Terapia Intensiva Pediátrica; Ergonomia; Enfermagem Pediátrica; Qualidade da Assistência à Saúde; Avaliação da Tecnologia Biomédica.

\section{RESUMEN}

Objetivo: Analizar la usabilidad de dos modelos de bombas de infusión en una Unidad de Cuidados Intensivos Pediátricos. Método: Estudio transversal con abordaje descriptivo exploratorio cuantitativo. Se realizó una tarea en ambiente controlado utilizando la bomba de infusión con 72 integrantes del equipo de enfermería de agosto a septiembre de 2018. Como base, se siguió la guía metodológica para los estudios de evaluación de Equipos de Asistencia Médica y el modelo de calidad en uso propuesto por NBR ISO/IEC 9126-1 Se utilizó análisis estadístico descriptivo, aplicando Test Exacto de Fisher, Test Binomial y Test de Mann-Whitney. Resultados: Hubo 91,7\% de tareas completadas. E1 modelo de bomba de infusión-2 se asoció ( $p<0,001)$ con la operatividad, las tareas cumplidas con no conformidades, el uso de la calculadora manual (medida de efectividad) y el tiempo para completar la tarea (medida de eficiencia). Conclusión: Las medidas de eficacia y eficiencia pueden mostrar un mejor contexto de usabilidad de las bombas de infusión e identificar fallas de interacción con el equipo de enfermería para mejorar en la práctica asistencial.

\section{DESCRIPTORES}

Bombas de Infusion; Unidades de Cuidado Intensivo Pediátrico; Ergonomía; Enfermería Pediátrica; Calidad de la Atención de Salud; Evaluación de la Tecnología Biomédica.

\section{REFERENCES}

1. Brasil. Ministério da Saúde; Secretaria de Ciência, Tecnologia e Insumos Estratégicos, Departamento de Ciência e Tecnologia. Diretrizes metodológicas: elaboração de estudos para avaliação de equipamentos médicos assistenciais [Internet]. Brasília; 2013 [citado 2019 jul. 19]. Disponível em: http://bvsms.saude.gov.br/bvs/publicacoes/diretrizes_metodologicas_elaboracao_estudos.pdf

2. Moreira APA, Escudeiro CL, Christovam BP, Silvino ZR, Carvalho MF, Silva RCL. Use of technologies in intravenous therapy: contributions to a safer practice. Rev Bras Enferm. 2017;70(3):595-601. doi: https://doi.org/10.1590/0034-7167-2016-0216

3. Lange K, Nowak M, Lauer W. A human factors perspective on medical device alarms: problems with operating alarming devices and responding to device alarms. Biomed Tech. 2016;61(2):147-64. doi: https://doi.org/10.1515/bmt-2014-0068

4. Grebin SZ, Echeveste MES, Magnago PF, Tanure RLZ, Pulgati FH. Estratégia de análise para avaliação da usabilidade de dispositivos médicos na percepção do usuário: um estudo com pacientes em tratamento de hemodiálise. Cad Saúde Pública. $2018 ; 34(8): e 00074417$. doi: https://doi.org/10.1590/0102-311x00074417

5. Schmettow M, Schnittker R, Schraagen JM. An extended protocol for usability validation of medical devices: research design and reference model. J Biomed Inform. 2017;69:99-114. doi: https://doi.org/ 10.1016/j.jbi.2017.03.010

6. Carayon P, Kianfar S, Li Y, Xie A, Alyousef B, Wooldridge A. A systematic review of mixed methods research on human factors and ergonomics in health care. App Ergon. 2015;51(1):291-321. doi: http://dx.doi.org/10.1016/j.apergo.2015.06.001

7. Gilbert RE. The human factor: designing safety into oncology practice. J Oncol Pract. 2016;12(10):884-87. doi: http://dx.doi.org/ 10.1200/ JOP.2016.013045

8. Ribeiro GSR, Silva RC, Ferreira MA, Silva GR. Violations of nurses in the use of equipment in intensive care. Texto Contexto Enferm. 2017;26(2):e6050015. doi: https://doi.org/10.1590/0104-07072017006050015

9. Roque KE, Tonini T, Melo ECP. Adverse events in the intensive care unit: impact on mortality and length of stay in a prospective study. Cad Saúde Pública. 2016;32(10):e00081815. doi: https://doi.org/10.1590/0102-311X00081815

10. Schnittker R, Schmettow M, Verhoeven F, Schraagen JMC. Combining situated cognitive engineering with a novel testing method in a case study comparing two infusion pump interfaces. App Ergon. 2016;55:16-26. doi: https://doi.org/10.1016/j.apergo.2016.01.004

11. Fernandes LGG, Tourinho FSV, Souza NL, Menezes RMP. Contribuição de James Reason para a Segurança do Paciente: reflexão para a prática de enfermagem. Rev Enferm UFPE On line. 2014;8(supl.1):2507-12. doi: 10.5205/reuol.5927-50900-1-SM.0807supl201440

12. Giuliano KK. IV Smart Pumps: the impact of a simplified user interface on clinical use. Biomed Instrum Technol. 2015;Suppl:13-21. doi: https://doi.org/10.2345/0899-8205-49.s4.13

13. Blandford A, Furniss D, Vincent C. Patient safety and interactive medical devices: realigning work as imagined and work as done. Clin Risk. 2014;20(5):107-10. doi: https://doi.org/10.1177/1356262214556550

14. Manrique-Rodríguez S, Sánchez-Galindo AC, Lorenzo-Pinto A, González-Vives L, López-Herce J, Carrillo-Álvarez Á, et al. Implementation of smart pump technology in a paediatric intensive care unit. Health Informatics J. 2015;21(3):209-22. doi: https://doi. org/10.1177/1460458213518058

15. Sowan AK, Gaffoor MI, Soeken K, Johantgen ME, Vaidya VU. Impact of computerized orders for pediatric continuous drug infusions on detecting infusion pump programming errors: a simulated study. J Pediatr Nurs. 2010;25(2):108-18. doi: https://doi.org/ 10.1016/j. pedn.2008.10.002

16. Gonçalves MG, Heineck I. Frequency of prescriptions of off-label drugs and drugs not approved for pediatric use in primary health care in a southern municipality of Brazil. Rev Paul Pediatr. 2016;34(1):11-7. doi: https://doi.org/10.1016/j.rppede.2015.06.023

17. Pham JC, Carson KA, Benson J, Doyle PA, ljagbemi M, Ravitz A, et al. comparison of automated versus manual programming of infusion pumps. Biomed Instrum Technol. 2016;50(4):242-51. doi: https://doi.org/10.2345/0899-8205-50.4.242 
18. ECRI Institute. 2019 Top 10 Technology Health Hazards. Executive Brief. A report from Health Devices [Internet]. Plymouth Meeting; 2019 [cited 2019 Dec 2]. Available from: https://www.ecri.org/Resources/Whitepapers_and_reports/Haz_19.pdf

19. Associação Brasileira de Normas Técnicas (ABNT). NBR ISO/IEC 9126-1. Engenharia de software: qualidade de produto: parte 1: modelo de qualidade. Rio de Janeiro: ABNT; 2003.

20. Associação Brasileira de Normas Técnicas (ABNT). NBR IEC 60601-2-24. Equipamento eletromédico: prescrições particulares para segurança de bombas e controladores de infusão. Rio de Janeiro: ABNT; 1999.

21. Borycki E. Trends in health Information technology safety: from technology-induced errors to curente approaches for ensuring technology safety. Healthc Inform Res. 2013;19(2):69-78. doi: https://doi.org/10.4258/hir.2013.19.2.69

22. Miller KE, Arnold R, Capan M, Campbell M, Zern SC, Dressler R, et al. Improving infusion pump safety through usability testing. J Nurs Care Qual. 2017;32(2):141-9. doi: http://dx.doi.org/doi:10.1097/NCQ.0000000000000208

23. Russell RA, Murkowski K, Scanlon MC. Discrepancies between medication orders and infusion pump programming in a paediatric intensive care unit. Qual Saf Health Care. 2010;19 Suppl 3:i31-5. doi: https://doi.org/10.1136/qshc.2009.036384

24. Ribeiro GSR, Silva RC, Ferreira MA, Silva GR. Slips, lapses and mistakes in the use of equipment by nurses in an intensive care unit. Rev Esc Enferm USP. 2016;50(3):419-26. doi: https://doi.org/10.1590/S0080-623420160000400007

25. Manrique-Rodríguez S, Sánchez-Galindo AC, López-Herce J, Calleja-Hernández MA, Iglesias-Peinado I, Carrillo-Álvarez A, et al. Risks in the implementation and use of smart pumps in a pediatric intensive care unit: application of the failure mode and effects analysis. Int J Technol Assess Health Care. 2014;30(2):210-7. doi: https://doi.org/10.1017/S0266462314000051

26. Norris B, West J, Anderson O, Davey G, Brodie A. Taking ergonomics to the bedside: a multi-disciplinary approach to designing safer healthcare. Appl Ergon. 2014;45(3):629-38. doi: https://doi.org/10.1016/j.apergo.2013.09.004

27. Schraagen, JM, Verhoeven, F. Methods for studying medical device technology and practitioner cognition: the case of user-interface issues with infusion pumps. J Biomed Inform. 2013;46(1):181-95. doi: http://dx.doi.org/10.1016/j.jbi.2012.10.005

28. Blijleven V, Koelemeijer K, Wetzels M, Jaspers M. Workarounds emerging from electronic health record system usage: consequences for patient safety, effectiveness of care, and efficiency of care. JMIR Hum Factors. 2017;4(4):e27. doi: https://doi.org/10.2196/humanfactors.7978

29. Liu K, Chan FY, Or CK, Sun DTF, Lai WS, So HY. Heuristic evaluation and simulated use testing of infusion pumps to inform pump selection. Int J Med Inform. 2019;131:103932. doi: https://doi.org/10.1016/j.ijmedinf.2019.07.011

30. Carayon P, Xie A, Kianfar S. Human factors and ergonomics as a patient safety practice. BMJ Qual Saf. 2014;23(3):196-205. doi: https:// doi.org/10.1136/bmjqs-2013-001812 